\title{
SpZ12-1, a negative regulator required for spatial control of the territory- specific Cyllla gene in the sea urchin embryo
}

\author{
David G.-W. Wang ${ }^{*}$, Carmen V. Kirchhamer, Roy J. Britten and Eric H. Davidson \\ Division of Biology 156-29, California Institute of Technology, Pasadena, CA 91125, USA \\ *Present address: Whitehead Institute/MIT Center for Genome Research, 1 Kendall Square, Building 30, Cambridge, MA 02139-1561, USA
}

\section{SUMMARY}

The CyIIIa cytoskeletal actin gene of the sea urchin Strongylocentrotus purpuratus is activated in late cleavage and expressed exclusively in the aboral ectoderm territory of the embryo. Previous gene transfer studies defined a 2.3 $\mathbf{k b}$ cis-regulatory region that is necessary and sufficient for correct temporal and spatial expression of a $\mathrm{CyIIIa} \cdot \mathrm{CAT}$ fusion gene. In this paper, a negative regulatory element within this region was identified that is required for repression of the CyIIIa gene in skeletogenic mesenchyme cells. The repression mediated by this regulatory element takes place after initial territorial specification. A cDNA clone

\section{INTRODUCTION}

In the sea urchin embryo, cleavage of blastomeres is invariant and gives rise to five polyclonal territories. Each of these embryonic territories develops into specific larval structures and those that have been studied are identified by unique spatial patterns of gene expression. The territories are: the aboral ectoderm, the oral ectoderm, the skeletogenic mesenchyme, the vegetal plate and the small micromeres. Territory-specific gene expression begins shortly after the segregation of lineage founder cells from one another at 3rd to 6th cleavage (reviewed by Davidson, 1986, 1989; Cameron and Davidson, 1991).

A well-characterized molecular marker for the aboral ectoderm is the CyIIIa cytoskeletal actin gene, which is transcriptionally activated late in cleavage and is expressed exclusively in the aboral ectoderm throughout embryonic development (Shott et al., 1984; Cox et al., 1986; Lee et al., 1986; Hickey et al., 1987; Akhurst et al., 1987). In earlier gene transfer experiments, a $2.3 \mathrm{~kb}$ CyIIIa regulatory region was found to direct correct spatial and temporal expression of a linked CAT reporter gene in the embryo (Flytzanis et al., 1987; Livant et al., 1988, 1991; Hough-Evans et al., 1987, 1988, 1990; Franks et al., 1990). At least 20 sites within this regulatory region where nuclear proteins bind with high specificity in vitro have been mapped in detail, as indicated in Fig. 1 (Calzone et al., 1988; Thézé et al., 1990). Several gene regulatory factors that interact at these sites with high specificity have been isolated and characterized (Calzone et al., 1991; Höög et al., 1991; Char et al., 1993; and unpublished data from encoding a DNA-binding protein with twelve $\mathrm{Zn}$ fingers (SpZ12-1) was isolated by probing an expression library with this cis-element. Deletion analysis of the SpZ12-1 protein confirmed that a DNA-binding domain is located within the $\mathrm{Zn}$ finger region. SpZ12-1 is the only DNAbinding protein in embryo nuclear extract that interacts with the specific cis-target sites required for repression of $C y I I I a^{\circ} \mathrm{CAT}$ in skeletogenic mesenchyme and is likely to be the trans factor that mediates this repression.

Key words: transcription factor, sea urchin gene regulation, CyIIIa

this laboratory). This report concerns the regulatory function of interactions that occur at two adjacent sites within the CyIIIa regulatory domain, and a DNA-binding factor which binds specifically at these sites (SpZ12-1). By mutating the SpZ12-1 sites, we showed that interactions at these sites are required specifically for spatial repression of the CyIIIa gene expression in skeletogenic mesenchyme cells at the gastrula stage. SpZ12-1 is the only factor interacting with this regulatory element in embryo nuclear extracts, and thus it is likely that it is a mesenchyme repressor for the CyIIIa gene.

\section{MATERIALS AND METHODS}

\section{Embryos}

Eggs of Strongylocentrotus purpuratus were prepared for injection as previously described (McMahon et al., 1985). The eggs were microinjected with approx. $2 \mathrm{pl}$ of injection solution after fertilization. The embryos were cultured to mesenchyme blastula stage (30 hours), or late gastrula stage (54 hours) for whole-mount in situ hybridization. The injection solution contained 40\% glycerol, $0.2 \mathrm{M} \mathrm{KCl}, 1500-3000$ molecules per pl of plasmid, and a 5-fold molar excess of carrier DNA.

\section{Whole-mount in situ hybridization}

Whole-mount in situ hybridizations were carried out according to the method of Ransick et al. (1993), but using a modified fixation procedure. Briefly, embryos were fixed in Streck Tissue Fixative (Streck Laboratories) at $4^{\circ} \mathrm{C}$ for 2-6 days. After a brief wash with filtered sea water and PBST buffer (PBS containing 0.1\% Tween-20) the embryos were equilibrated with hybridization buffer $(50 \%$ 


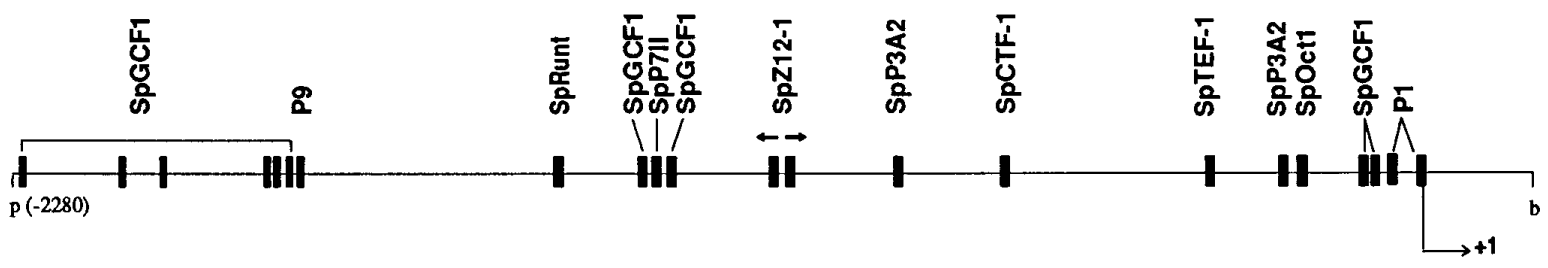

Fig. 1. The $5^{\prime}$ regulatory domain of the CyIIIa cytoskeletal actin gene. Black boxes represent the specific sites of interaction with nuclear proteins from blastula stage embryos in the 5'-flanking region of the CyIIIa gene that extends from -2280 to +235 bp (Calzone et al., 1988 ; Thézé et al., 1990; Coffman et al., unpublished data). The bent arrow indicates the transcription start site. Note that there are two adjacent SpZ12-1 binding sites in inverse orientation within this region. Restriction sites that flank this region are BamHI (b) and PstI (p). Nuclear factors binding to the sites are indicated: SpGCF-1 is a factor of novel sequence that recognizes a G/C-rich motif (Coffman and Davidson, 1992; R. W. Zeller and E. H. Davidson, unpublished); SpRunt in an S. purpuratus factor homologous to the Drosophila runt protein (J. A. Coffman and E. H. Davidson, unpublished data); SpP3A2 and SpP7II are both factors of novel sequence, which may be involved in distinct negative control functions of the CyIIIa regulatory system (Hough-Evans et al., 1990; Calzone et al., 1991; C. Kirchhamer and E. H. Davidson, unpublished data; J. A. Coffman and E. H. Davidson, unpublished data); SpCTF-1 is a CCAAT binding factor (Calzone et al., 1988; Barberis et al., 1987); SpOct-1 is an octamer factor (Char et al., 1993). SpTEF1 is an S. purpuratus factor homologous to the human enhancer factor TEF-1 (J. Xian and E. H. Davidson, unpublished data). P9 and P1 are not yet characterized. All of these sites of interaction appear to have functional roles in control of CyIIIa expression (with the possible exception of the P9 interaction, which has not yet been studied).

formamide, $10 \% \mathrm{PEG}$, and $0.6 \mathrm{M} \mathrm{NaCl}, 5 \mathrm{mM} \mathrm{EDTA}, 20 \mathrm{mM}$ Tris, $\mathrm{pH} 7.5,500 \mu \mathrm{g} / \mathrm{ml}$ yeast tRNA, $0.1 \%$ Tween-20, and $2 \times$ Denhardt's solution). It is worth noting that proteinase $\mathrm{K}$ digestion is not necessary when Streck fixative is used. Hybridization was carried out at $45^{\circ} \mathrm{C}$ overnight with a digoxigenin-labeled CAT antisense RNA probe at $0.02 \mathrm{ng} / \mu \mathrm{l}$. Three washes of $1 \times \mathrm{SSC}$ at $65^{\circ} \mathrm{C}$ were followed by incubation with alkaline phosphatase-conjugated anti-digoxigenin $\mathrm{F}(\mathrm{ab})$ (Boehringer Mannheim Biochemicals). The chromogenic reaction was performed with NBT and BCIP (Boehringer Mannheim Biochemicals). After dehydration, the embryos were mounted for observation.

\section{Construction of CyIlla.CAT and $\mathrm{mZ12CyIIIa \cdot CAT}$ \\ (1) Cylla.CAT}

The $C y I I I a \cdot C A T$ construct contains a $4.5 \mathrm{~kb}$ genomic DNA fragment that includes the $5^{\prime} C y I I I a$ regulatory region, transcription start site, and $5^{\prime}$ leader sequence of the CyIIIa primary transcript (Akhurst et al., 1987; Flytzanis et al., 1987). The $C y I I I a \cdot C A T$ construct was linearized for microinjection at a unique NotI site (Fig. 3).

\section{(2) $m Z 12 C y I I a \cdot C A T$}

Site-directed mutagenesis of the SpZ12-1 binding sites was carried

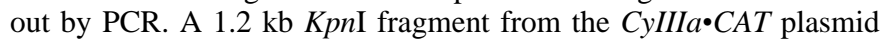
that included the two SpZ12-1 binding sites was subcloned into the pBluescript KS (+) vector at its KpnI site, to generate pBlue HE. The site-specific substitutions were made with two overlapping mutagenic oligonucleotide primers (DS-T7 and DS-T3). The sequence of these primers, with the overlapping region underlined, and the substituted nucleotides indicated in bold type, was as follows.

Primer for SpZ12-1 binding site I: $-\mathrm{DS}-\mathrm{T} 7$,

5'-ACAAACAATATGGCTTGACCTATTGATTCCTCTGTACCGTGCATTCTG-3'

Primer for SpZ12-1 binding site II: $-\mathrm{DS}-\mathrm{T} 3$,

\section{5'-GTCAAGCCATATTGTTTGTCCTATTGGTTCCTCACTAATGTATGCCGTTC-3'}

The first round of PCR was designed to introduce base substitutions into the SpZ12-1 binding sites I and II in two separate fragments using a combination of mutant and non-mutant primers. The reactions were performed in $25 \mu \mathrm{l}$ containing $100 \mathrm{ng}$ template DNA (pBlue HE), $0.4 \mathrm{mM}$ DS-T7 or DS-T3 primers, $4 \mathrm{mM} \mathrm{T7}$ or T3 primers, 0.4 $\mathrm{mM}$ each dNTP, and one unit of Vent DNA polymerase (New England Biolabs), with 15 cycles of amplification $\left(94^{\circ} \mathrm{C}, 30\right.$ seconds; $55^{\circ} \mathrm{C}, 1$ minute; $72^{\circ} \mathrm{C}, 1$ minute). The second round of PCR reactions were carried out to rejoin the two purified PCR fragments (100 ng each) using the external T7 and T3 primers. Following KpnI digestion of the final PCR product, the $m Z 12 C y I I I a{ }^{\circ} C A T$ fusion gene was generated by inserting the $1.2 \mathrm{~kb}$ fragment back into the $C y I I I a \cdot C A T$ fusion gene at the KpnI site (see Fig. 3).

\section{Cloning of the SpZ12-1 gene}

The sequence of the SpZ12-1 binding site I was used to generate the complementary oligonucleotide probe shown below (Calzone et al., 1988; Thézé et al., 1990; Wang et al., unpublished data).

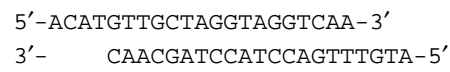

A $\lambda$ ZAP (Stratagene) cDNA expression library of 4-hour embryo poly(A) RNA was screened with this probe as described by Vinson et al. (1988) and Höög et al. (1991). One positive clone was isolated and both strands were sequenced using subclones generated by exonuclease III digestion. Sequencing was performed by the dideoxy method, using Sequenase reagents (US Biochemical Corp.).

\section{Expression, purification and renaturation of bacterial proteins}

A T7 RNA polymerase based expression system (Studier and Moffat, 1986) was used to prepare recombinant SpZ12-1 protein. Three different expression constructs (SpZ12-1, SpZ12-1 $\Delta$ ZF and SpZ12$\Delta \mathrm{N})$ were made in pET vectors. The SpZ12-1 construct contains an EcoRI-NciI fragment of SpZ12-1 cDNA. The fragment was end-filled and ligated into the pET3c vector at the BamHI site. The SpZ12-1 $\mathrm{ZF}$ construct, which includes an EcoRI-MluI fragment of SpZ12-1 cDNA, was generated by ligating the end-filled fragment into the pET3c vector at the BamHI site. The SpZ12- $1 \Delta \mathrm{N}$ construct contains an EspI-NciI fragment of SpZ12-1 cDNA, prepared by joining the end-filled fragment into the BamHI site of pET3b vector. Expression of SpZ12-1 proteins in E. coli was performed as described by Studier et al. (1986) and Calzone et al. (1991). Briefly, IPTG-induced bacterial cells were harvested by centrifugation, and the pellet was resuspended in $50 \mathrm{mM}$ Tris- $\mathrm{HCl}(\mathrm{pH} 8.0), 2 \mathrm{mM}$ EDTA, $0.1 \%$ Triton $\mathrm{X}-100$, and $1 \mathrm{mM}$ PMSF. Following a 1-hour incubation with $1 \mathrm{mg} / \mathrm{ml}$ lysozyme on ice and brief sonication, $15,000 \mathrm{~g}$ pellets were washed in $50 \mathrm{mM}$ Tris- $\mathrm{HCl}$ ( $\mathrm{pH} 8.0$ ), $50 \mathrm{mM} \mathrm{NaCl}, 5 \mathrm{mM}$ EDTA, $1 \%$ Triton $\mathrm{X}-100,25 \%$ sucrose, and $1 \mathrm{mM}$ PMSF. After centrifugation at $15,000 \mathrm{~g}$, the washed pellets were resuspended in $20 \mathrm{mM}$ Hepes- $\mathrm{KOH}$ (pH 7.9), $0.1 \mathrm{mM}$ EDTA, $1 \mathrm{mM}$ DTT, and $5 \mathrm{M}$ guanidine hydrochloride. In order to renature the SpZ12-1 proteins, guanidine hydrochloride was diluted from 5 to $0.5 \mathrm{M}$ with $10 \mathrm{mM}$ Hepes- $\mathrm{KOH}$ (pH 7.9), 
$100 \mathrm{mM} \mathrm{KCl}, 0.2 \mathrm{mM} \mathrm{ZnCl}$, $0.1 \mathrm{mM}$ PMSF, $1 \mathrm{mM}$ DTT, 0.1\% NP40 and $20 \%$ glycerol in three serial two-fold dilution steps. At each step the solution was incubated at $4{ }^{\circ} \mathrm{C}$ for $4-6$ hours. After renaturation, insoluble protein was eliminated by centrifugation at $15,000 \mathrm{~g}$ and the supernatant was stored at $-70^{\circ} \mathrm{C}$.

\section{Antibodies and immunoblots}

SpZ12-1 $\Delta$ ZF protein (Fig. 8) was expressed from E. coli as described above and further purified by SDS-PAGE. The purified protein was used for the immunization of rabbits. The specificity of the antiserum preparations (Cocalico Biological, Inc.) was tested by using bacterially expressed SpZ12-1 protein and whole embryo lysate. Immunoblots were carried out according to Calzone et al. (1991).
Immunoreactive proteins were visualized by the ECL detection system (Amersham) following procedures recommended by the supplier.

\section{RESULTS}

\section{Expression pattern of the control Cyllla.CAT fusion gene at late gastrula stage}

In this study we utilized a sensitive whole-mount in situ hybridization procedure to locate CAT transcripts deriving from injected $C y I I I a \cdot C A T$ fusion constructs (Ransick et al.,
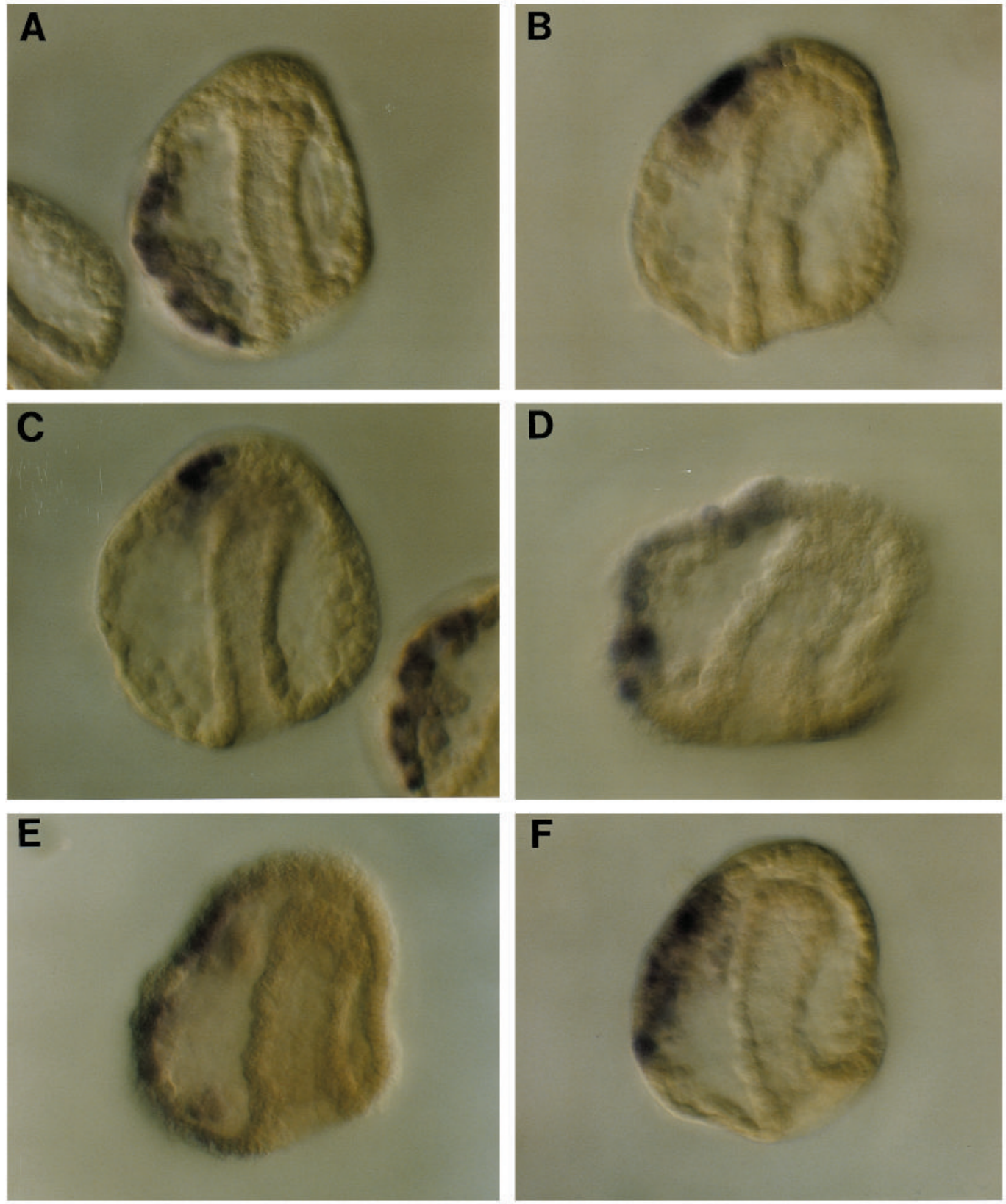

Fig. 2. Expression pattern of the $C y I I I a \bullet C A T$ fusion gene at late gastrula stage. The spatial distribution of CAT transcripts in late gastrula-stage embryos was detected by whole-mount in situ hybridization, using a digoxigenin-labeled antisense CAT RNA probe. Six late gastrula-stage embryos with expression restricted to the aboral ectoderm are shown, oriented with the oral surface to the right. (A) An embryo showing extensive staining along the aboral ectoderm extending to the lower aboral-oral boundary. (B,C) Two embryos displaying a patch of labeled cells toward the upper aboral-oral boundary. (D,E,F) Three embryos expressing CAT transcripts in large regions of the aboral ectoderm. 
1993; Yuh et al., 1994). The previous experiments on CyIIIa $C A T$ expression cited above had relied on in situ hybridization of radioactive probes to embryo sections. The expression pattern of the complete $C y I I I a \cdot C A T$ fusion gene at late gastrula stage (54 hours postfertilization), as visualized by the whole-mount hybridization procedure, is shown in Fig. 2. Fig. 2A displays an embryo with aboral ectoderm expression close to the lower aboral-oral boundary; in Fig. 2B,C two embryos are shown with a patch of positive cells toward the upper aboral-oral boundary. Fig. 2D-F show three embryos with a large portion of the aboral ectoderm stained. The mosaic pattern of CAT expression observed in these stained embryos (Fig. 2A-F) is due to mosaic incorporation of the fusion gene during the first several cleavages (Hough-Evans et al., 1988; Livant et al., 1991). Of the hundreds of embryos expressing the $C y I I I a \cdot C A T$ fusion gene that were examined, approximately 95\% showed expression confined to the aboral ectoderm. Approximately $70 \%$ of all the injected embryos express CAT transcripts. Quantitative data for four different experiments with the control $C y I I I a \bullet C A T$ construct are given in Tables 1 and 2.

\section{Ectopic expression pattern of the $m Z 12 C y I I a \cdot C A T$ fusion gene at late gastrula stage}

Two adjacent SpZ12-1 binding sites were initially identified by
Calzone et al. (1988; there referred to as 'P6' sites). A preliminary experiment showed that deletion of a region of about 200 bp ( -1033 to -821$)$, which includes these sites, sharply derepresses spatial regulation of the CyIIIa gene, causing ectopic expression in mesenchyme cells (data not shown). To assess the contribution of the SpZ12-1 binding sites to the spatial control of CyIIIa gene expression, both sites within the $5^{\prime}$ CyIIIa regulatory region were mutated, generating the $m Z 12 C y I I I a \cdot C A T$ fusion gene. As shown in Fig. 3A, these sites occur in reverse orientation 13 base pairs apart. They include a $9 / 10$ nucleotide pair reverse repeat of the sequence TGTTGC(T/C)AGG. By site-directed mutagenesis we altered each of the nucleotides in this core sequence from purine to pyrimidine or vice versa. As shown in Fig. 3B, these substitutions actively abolish DNA-binding activity (Fig. 3B).

Patterns of expression of the $m Z 12 C y I I I a \cdot C A T$ fusion gene at late gastrula stage were determined by whole-mount in situ hybridization as above. The mutation has a remarkable effect on spatial expression of the fusion gene, evidently resulting in its derepression in mesenchyme cells, but only in mesenchyme cells. Examples are shown in Fig. 4. Two major phenotypes occur, viz. embryos displaying expression in both mesenchyme cells and aboral ectoderm cells (Fig. 4A,B,D-F), and embryos with expression only in mesenchyme cells (Fig. 4C). A detailed analysis of about 200 stained embryos is summarized in Table

Table 1. Ectopic expression pattern of the $m Z 12 C y I I I a^{\circ} \mathrm{CAT}$ fusion gene in mesenchyme cells at late gastrula stage (approx. 54 hours)

\begin{tabular}{|c|c|c|c|c|c|}
\hline Construct & Batch & $\begin{array}{l}\text { Total } \\
\text { embryos } \\
\text { stained } *\end{array}$ & $\begin{array}{l}\text { Embryos } \\
\text { with correct } \\
\text { expression } \dagger\end{array}$ & $\begin{array}{l}\text { Embryos with } \\
\text { ectopic } \\
\text { expression in } \\
\text { mesenchyme } \\
\text { cells }\end{array}$ & $\begin{array}{c}\text { Ectopic expression } \\
\text { as \% of } \\
\text { stained } \\
\text { embryos } \ddagger\end{array}$ \\
\hline \multirow{3}{*}{$\begin{array}{c}C y I I I a \cdot C A \mathrm{~T} \\
\quad(\text { control })\end{array}$} & 1 & 41 & 40 & 1 & 2.4 \\
\hline & 2 & 45 & 41 & 4 & 8.9 \\
\hline & Total & 86 & 81 & 5 & 5.6 \\
\hline \multirow[t]{4}{*}{$m Z 12 C y I I I a \cdot C A T$} & 1 & 48 & 26 & 22 & 46 \\
\hline & 2 & 53 & 30 & 23 & 44 \\
\hline & 3 & 95 & 50 & 45 & 47 \\
\hline & Total & 196 & 106 & 90 & 46 \\
\hline $\begin{array}{l}*_{\text {Embryos were scored if two or more cell }} \\
\text { †mbryos with correct expression were sc } \\
\text { †ctopic expression as } \% \text { of stained embr }\end{array}$ & $\begin{array}{l}\text { re stain } \\
\text { if two } \\
=\left[\sum \mathrm{en}\right.\end{array}$ & $\begin{array}{l}\text { re cells } \\
\text { stained }\end{array}$ & $\begin{array}{l}\text { ained in a pa } \\
\text { ally } / \sum \text { stain }\end{array}$ & $\begin{array}{l}\text { thin the abora } \\
\text { ryos }] \times 100 \text {. }\end{array}$ & lerm. \\
\hline
\end{tabular}

Table 2. Expression pattern of $m Z 12 C y I I I a C A T$ fusion gene at mesenchyme blastula stage (approx. 30 hours)

\begin{tabular}{|c|c|c|c|c|c|}
\hline Construct & Batch & $\begin{array}{l}\text { Total } \\
\text { embryos } \\
\text { stained* }\end{array}$ & $\begin{array}{l}\text { Embryos } \\
\text { with correct } \\
\text { expression } \dagger\end{array}$ & $\begin{array}{l}\text { Embryos with } \\
\text { ectopic } \\
\text { expression in } \\
\text { mesenchyme } \\
\text { cells }\end{array}$ & $\begin{array}{l}\text { Ectopic expression } \\
\text { as } \% \text { of } \\
\text { stained } \\
\text { embryos } \ddagger\end{array}$ \\
\hline \multirow{3}{*}{$\begin{array}{c}C y I I I a \cdot C A \mathrm{~T} \\
(\text { control })\end{array}$} & 1 & 18 & 18 & 0 & 0 \\
\hline & 2 & 36 & 36 & 0 & 0 \\
\hline & Total & 54 & 54 & 0 & 0 \\
\hline \multirow[t]{3}{*}{$m Z 12 C y I I I a \cdot C A T$} & 1 & 22 & 22 & 0 & 0 \\
\hline & 2 & 48 & 46 & 2 & 4 \\
\hline & Total & 70 & 68 & 2 & 3 \\
\hline $\begin{array}{l}\text { *Embryos were scored if two or more cell } \\
\dagger \text { Embryos with correct expression were sc } \\
\ddagger \text { Ectopic expression as } \% \text { of stained embry }\end{array}$ & $\begin{array}{l}\text { ere stain } \\
\mathrm{d} \text { if two } \\
=\left[\sum \mathrm{en}\right.\end{array}$ & $\begin{array}{l}\text { re cells } \mathrm{x} \\
\text { stained }\end{array}$ & $\begin{array}{l}\text { ained in a pa } \\
\text { ally } / \sum \text { stain }\end{array}$ & $\begin{array}{l}\text { ithin the ectode } \\
\text { bryos }] \times 100 \text {. }\end{array}$ & \\
\hline
\end{tabular}


A

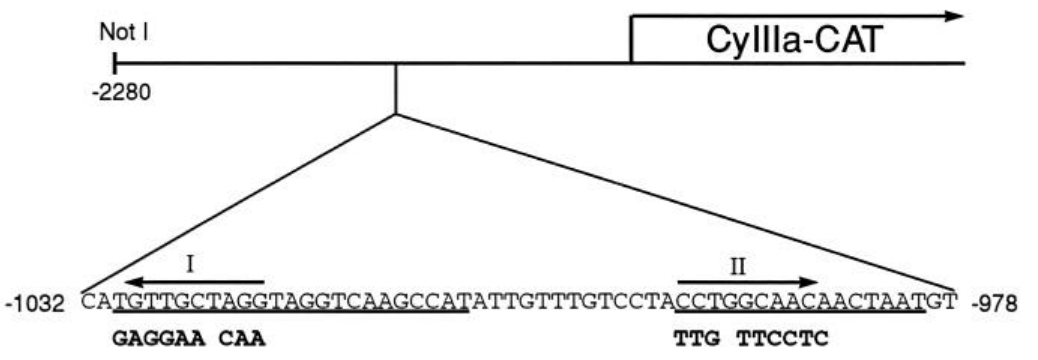

B

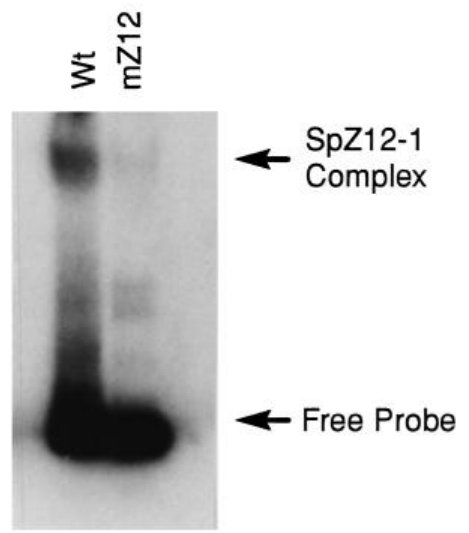

Fig. 3. $m Z 12 C y I I I a \cdot C A T$ fusion gene and mutated target sites. (A) A schematic representation of the $m Z 12 C y I I I a \bullet C A T$ fusion gene. The $m Z 12 C y I I I a \cdot C A T$ fusion gene includes the 5' CyIIIa regulatory sequence and portions of a non-translated exon, extending from -2280 to +235 bp relative to the transcription start site. The sequences of two adjacent SpZ12-1 binding sites, I and II, in inverse orientation are at -1030 to -1008 and -994 to $-979 \mathrm{bp}$, respectively (underlined). Underlined sequences are derived from the DNase I footprinting experiment shown below. The arrows indicate the inversely repeated core target site sequences noted in text. Substituted nucleotides in the mZ12 mutant gene are indicated below, in bold type. (B) DNA binding activity of the wild-type (Wt) and the mutant (mZ12) SpZ12-1 binding sites. ${ }^{32} \mathrm{P}-1$ labeled probes include the two adjacent SpZ12-1 binding sites, contained in the DNA fragment that extends from positions -1082 to -894 of the $5{ }^{\prime}$ CyIIIa regulatory region. Gel shift assays were carried out using blastula-stage nuclear extracts as previously described (Calzone et al., 1988). The nine nucleotide substitutions within each of the SpZ12-1 binding sites suffice to abolish all DNA binding activity, and only the free probe is observed.

1. About the same fraction of embryos express the $m Z 12 C y I I I a \cdot C A T$ fusion genes as they do the CyIIIa $\bullet C A T$ control construct. However, $46 \%$ of embryos bearing the $m Z 12 C y I I I a \cdot C A T$ fusion gene display ectopic mesenchyme cell expression. This is 8 -fold higher than the low level of ectopic expression observed in the control CyIIIa $C A T$ embryos. Importantly, ectopic expression is confined to skeletogenic mesenchyme, and is not seen in secondary mesenchyme, as judged from the position of the stained cells at this stage of embryogenesis. These data indicate that a negative regulatory interaction mediated by the SpZ12-1 binding sites is required for repression of the CyIIIa gene in skeletogenic mesenchyme cells at the late gastrula stage.

\section{Expression pattern of the $m Z 12 C y I l l a \cdot C A T$ fusion gene at mesenchyme blastula stage}

We wished to determine whether the negative control of CyIIIa expression in mesenchyme cells that is mediated by the SpZ121 sites is part of the initial aboral ectoderm specification mechanism. Thus we examined the expression of the $m Z 12 C y I I I a \cdot C A T$ construct at earlier stages. At the mesenchyme blastula stage, the skeletogenic mesenchyme cells have just ingressed into the blastocoel and can be easily identified morphologically, though at this stage it is difficult to distinguish aboral from oral ectoderm. Surprisingly, in these experiments we observed CAT transcripts exclusively in the ectoderm in almost all of the embryos staining for CAT RNA. No ectopic expression was detected in mesenchyme cells at this stage, in contrast to the late gastrula stage, as just discussed. Three typical embryos displaying CAT expression in the ectoderm but not in the newly ingressed skeletogenic mesenchyme cells, are shown in Fig. 4G-H. As indicated in Table 2, only $3 \%$ of the stained embryos from this series of experiments show ectopic expression in mesenchyme cells, which is probably indistinguishable from the control $(C y I I I a \cdot C A T)$ level. It should be noted that the possibility of ectopic expression in the oral ectoderm at this stage cannot be excluded, even though it is unlikely (i.e., since no oral expression is seen in gastrula stage embryos bearing the $m Z 12 C y I I I a \cdot C A T$ fusion). Thus the repression of mesenchyme expression mediated by the SpZ12-1 binding sites is a later control function, which is required to maintain ectodermal expression of the CyIIIa gene only after gastrulation.

\section{Molecular cloning of the SpZ12-1 gene}

A cDNA clone, designated SpZ12-1, was isolated by screening a 4-hour sea urchin embryo $\lambda Z A P$ expression library with an oligonucleotide probe containing multiple SpZ12-1 binding sites (Vinson et al., 1988; Höög et al., 1991). Nucleotide sequence analysis of a full-length SpZ12-1 cDNA clone indicated an open reading frame of 1779 bp (Fig. 5). This reading frame encodes a 593 amino acid protein, the predicated relative molecular mass of which is about $70 \times 10^{3}$.

The deduced amino acid sequence of the SpZ12-1 protein reveals a potential DNA-binding domain consisting of twelve tandem $\mathrm{Zn}$ fingers (Fig. 5A). The finger domain is located near the carboxyl terminus and occupies more than $50 \%$ of the entire protein. All twelve fingers of the SpZ12-1 protein are variants of the TFIIIA type of $\mathrm{Zn}$ finger, the consensus amino acid sequence of which is Tyr/Phe-X-Cys- $\mathrm{X}_{2 / 4}-\mathrm{Cys}-\mathrm{X}_{3}-\mathrm{Phe}-$ $\mathrm{X}_{5}-\mathrm{Leu}-\mathrm{X}_{2}-\mathrm{His}-\mathrm{X}_{3}-\mathrm{His}-\mathrm{X}_{5}$, where $\mathrm{X}$ may represent a variety of different amino acid (Berg et al., 1990; Pavletich et al., 1991, 1993). In each case, the cysteines are separated by two amino acids and each finger is connected with the next by a Thr-Gly-Glu-Lys-Pro consensus linker. Each of these sequences is capable of binding a zinc ion via the cysteine and 

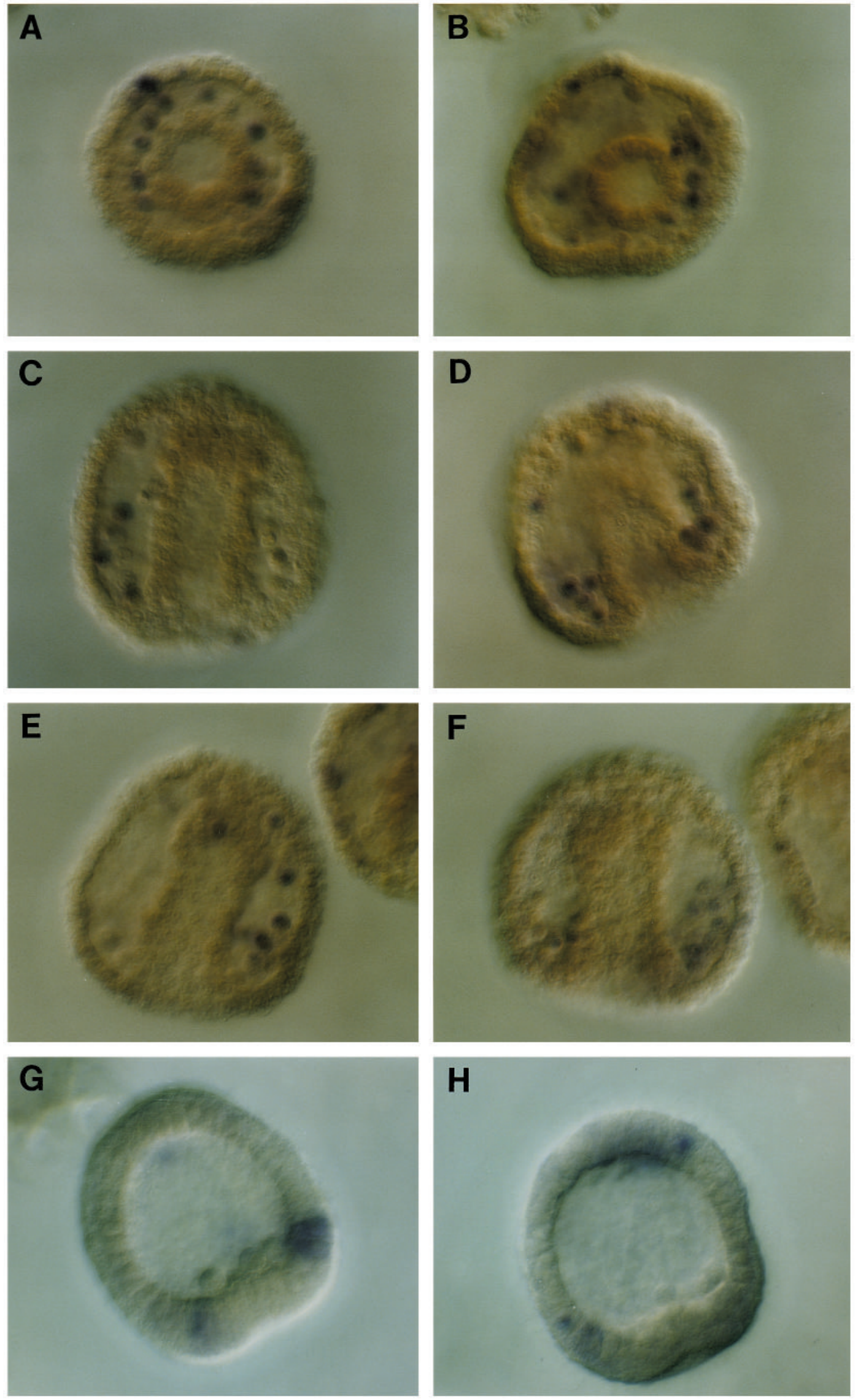

Fig. 4. Expression pattern of the $m Z 12 C y I I I a \cdot C A T$ fusion gene at gastrula stage and mesenchyme blastula stage. $(\mathrm{A}, \mathrm{B})$ Gastrula-stage embryos expressing CAT transcripts in closely spaced skeletogenic mesenchyme cells surrounding the archenteron, and along the inner ectodermal wall, vegetal view. Note that both embryos show a patch of stained cells in the aboral ectoderm toward the top left sides. (C-F) Side views, vegetal pole down.

The archenteron, topped with delaminating secondary mesenchyme cells, can be seen in the optical sections shown. (C) A gastrula-stage embryo in which expression occurs only in skeletogenic mesenchyme cells.

(D-F) Three other gastrulastage embryos displaying expression in skeletogenic mesenchyme cells. In other optical sections it can be seen that these particular embryos also express CAT transcripts in the aboral ectoderm. (G) A mesenchyme blastula-stage embryo showing staining in the ectoderm close to the vegetal plate, but not in the ingressed skeletogenic mesenchyme cells. (H) A mesenchyme blastula-stage embryo with expression located in the ectoderm closer to the animal pole, but no expression in the newly ingressed skeletogenic mesenchyme. 
histidine side chains to generate structural configurations that are essential for DNA binding (Berg et al., 1990). Fig. 6B shows sequence alignment of SpZ12-1 and Drosophila Krüppel $\mathrm{Zn}$ fingers (Rosenberg et al., 1986). These two finger proteins share all the consensus amino acids of the TFIIIA type of $\mathrm{Zn}$ finger, but also display a great deal of similarity in the region represented by the terminal ' $\mathrm{X}_{5}$ ' in this canonical consensus (see shading in Fig. 5B). Computer searches of GenBank with the protein sequence outside of the $\mathrm{Zn}$ finger domain did not reveal significant similarities to any other known proteins.

\section{Characterization of the SpZ12-1 protein}

Since the sequence analysis of the SpZ12-1 protein revealed twelve Zn fingers near the carboxyl terminus, it is likely that a potential DNAbinding domain is located within this region. To test this possibility, gel shift assays were performed to compare the DNA-binding activity of the wild-type and two deletion mutants of the SpZ12-1 protein. DNA fragments encoding the fulllength sequence (SpZ12-1), the amino-terminal region (SpZ12$1 \Delta \mathrm{ZF}$ ), and the $\mathrm{Zn}$ finger domain $(\mathrm{SpZ} 12-1 \Delta \mathrm{N})$ of the SpZ12-1 protein were cloned into pET expression vectors (Studier et al., 1986), as shown in Fig. 6A. The encoded proteins were expressed and purified from Escherichia coli,

Fig. 5. Sequences of SpZ12-1 cDNA and protein, and sequence similarities of the $\mathrm{Zn}$ finger domain between the SpZ12-1 and Krüppel proteins (Rosenberg et al., 1986). (A) The complete nucleotide sequence and the deduced amino acid sequence of the SpZ12-1 cDNA are shown. The Zn finger region is underlined. The numbered bent arrows below the amino acid sequence mark the positions of the twelve zinc fingers. The GenBank accession number is U19831. (B) Alignment of $\mathrm{Zn}$ finger sequences of the SpZ12-1 and Krüppel protein. The fingers of both proteins are numbered on the left side. Positions and amino acids that are identical among the $\mathrm{Zn}$ fingers are shaded.
A 1 AATTCGGCCGATTCGGGCCCGTGTCACATCCAGGAGAGATCCAGCACAGCAGACGACAAAATGACACAGGCGATGGATCTCTCTAAGAaA 91 CGAAAAAGAGATGCACCTATACCGGTCACAGTGCCGGTTATAGCACCGGTTACAGCACAGGTAACCATTAAACGGGAGCCAGTGGAGGAA $\begin{array}{llllllllllllllllllllllllllllllll}7 & R & K & R & D & A & P & I & P & V & T & V & P & V & I & A & P & V & T & A & Q & V & T & I & K & R & E & P & V & E & E\end{array}$

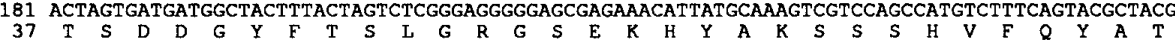

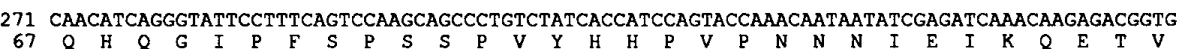
361 ACGGACGAAGATAGGTGCGAGGTGTGCTTCAAACCTTACGATAATGCAGCACATGCGAGGACTACTTTCCGTTATCAACTGCATGATCTG $\begin{array}{lllllllllllllllllllllllllllllllll}97 & T & D & E & D & R & C & E & V & C & F & K & P & Y & D & \text { N } & \text { A } & \text { A } & \text { H } & \text { A } & \text { R } & \text { T } & \text { T } & \text { F } & \text { R } & \text { Y } & \text { Q } & \text { L } & \text { H } & \text { D } & \text { L }\end{array}$

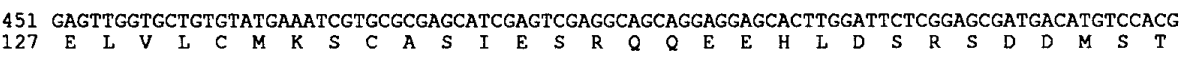
541 GCTGAAGATGAGACGGACAGCGGGTCGCAGGATACAGGGAGCTCGGAACGACAAGAGAGGTATGAGCAGTTCCGTGAAGAGTATCAGGGA

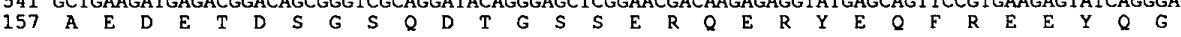

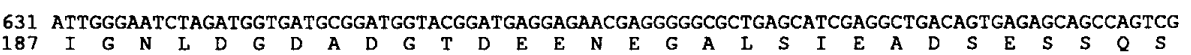
721 GAGCCATTCACAAGACCATACATTGCCGGTGGGTCGCAGTACATTGACGGGATAGCAACCATCTGGGCCAGATCCAGAGTGTCTTCATGG $\begin{array}{llllllllllllllllllllllllllllllllllll}217 & E & P & F & T & R & P & Y & I & A & G & G & S & Q & Y & I & D & G & I & A & T & I & W & A & R & S & R & V & S & S & W\end{array}$ 811 AGTGAGGCCCTACGAATGCAAAACTGCGGGAAACGGTTCGCCCAGAAGAGCTGTCTTACGCGTCACACCAAGATCCACACCGGAGAGAGA

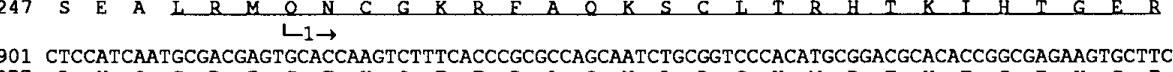
901 CTCCATCAATGCGACGAGTGCACCAAGTCTTTCACCCGCGCCAGCAATCTGCGGTCCCACATGCGGACGCACACCGGCGAGAGTGCTTC

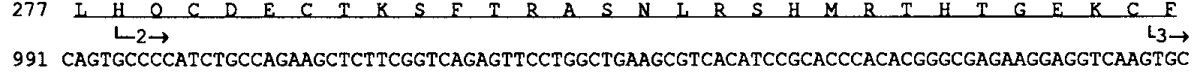

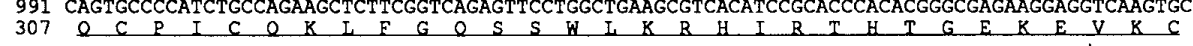
1081 CCGCTCTGCAGCAAGTGGGTCAGCTCCACGACCAGTCTTCAGTCCCATATGAGAACACACACGGGGGAGAAACCCTTCGCCTGCCTCATA

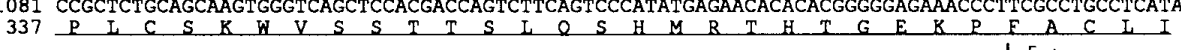
1171 TGTGACAAGAGCTTCAGTGTCAAGTGCACCCTGACGGTTCATATGCGTATCCACACAGGCAACAAGCCATACGTGTGTGAGGTGTGTGGT

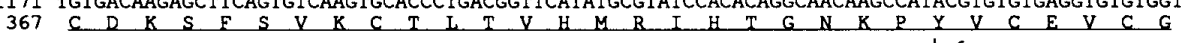
261 GCTGCATTCATACAGGGGACCCAGCTGTCCACTCACATGCGGGTGCATACGGGTGAGAAGCCATACATGTGTGAGATCTGTCATCGGCAG

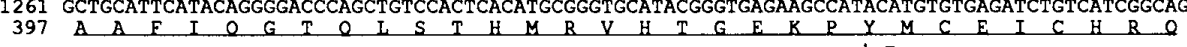
1351 TTCGGCAAGAAAGACAACCTCCTCACCCATGTCAAGATTCACACTGAAGGGCAGAATTTTGACTGCAAGTTCTGCAACCTACGTTTCAAC

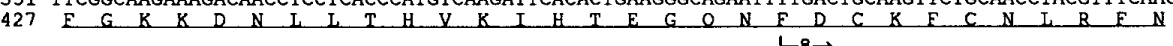
441 AACTCTGAGGAGCTCAAGACCCATACCCTGATCCATATAGAAGAGAGACCATTCCAGTGTGAAGTGTGCAACAAAGCCTTCAAGAGAAAG 457 N S E E L K T H I I I H I E E R R F Q C E V C N K A F K R K ᄂ $\rightarrow \rightarrow$

1531 GACAACCTTAAAGAACACATTAAGGTTCACACCAAAGAGAAGCCTTTTAGCTGTGAGGTTTGCAAAGAGGCCTTCTCCAACGGCAGCCAT

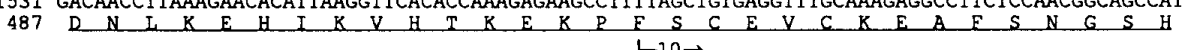
ᄂ $10 \rightarrow$

1621 CTTAAGGTCCACATGCGACGTCACACGGGGGACAAGCCCTACTCCTGTGAGCTCTGCGGGAAGTGCTTCACCCAGAGCAGTAGCTTGAAG

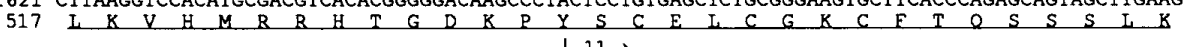
ᄂ $11 \rightarrow$

1711 ACCCACTACCTGATCCACACCGGTGAGAAACCTTACTCCTGTACTATCTGCCATGCACTCTTCACCCGCAATGCCAGCGTCAAGAAGCAC

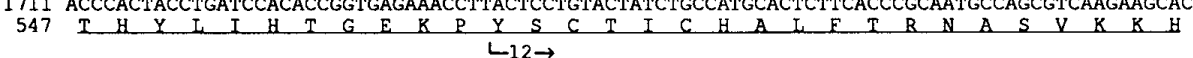
1801 ATGAAGAGAGCCCACAATGCCGACATGCCGGGACCAGAGGAGGCGTCTGAATGAGTGGGCCTCAGAGCAGTAGCTTAAAGACCCACTACC

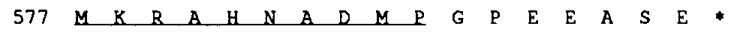

1891 TGATCCGCACCGGTGAGAAACCTTATTCCTGGGGCGCGTTTCACAAAACTTGTCATTGAACAAAGGCTTTGTGAAACGGTCCCTGTACT 1981 ATCTGCCAGGCGCTCTTCACCCGCAACGCACTCTTCAAACACTATGCCACCATGCCGGGACCGGACGATGCGTCTGAGTGAGCAGCCCTC 2071 GAGGAACCACTGGGAGGGAGTGAGTCAGCGGAGGTTAGGTACAGTCAAACCTGCTTTAGTGACCACCTGTCTACAAAGACCGCCTGTCTA 2161 TAAAGACCACATGTTTTGTTTCCCTTGAAATTGTTTCTCATTGAAACATGTACTATTAAAGGAACCTGTCTACAAAGACAATTTTTGTG 2251 TATCCCTTGGGTGGTCGCTTTAGACAGGTTTGACTGTAGTTGTTGGTGTCACCATCCAACTTTTGTTTTGTATTTTTCTGATATGCACAC 2341 GGGCCTTTGTATGTGTAGATATGATGAGGTGTATTTTATACGTATTTATGTCTTTTCTAAATGATTAACTAAATTGATTCAGATGTTTTT 2431 CTCTGTGAACGATTGACTGATTGTAACTTAAAATCAACCAGTTAATTTGTTTGTTAAATAGATAAACCCACAATTATGAGGGAAATTTAT 2521 GTATACCTTTTGTAAACAATATGAAAAATAGTATGTCTGTTCATGTAGTTTCCATCTTATAAGTGTATAGTTAAATCTATTTGAAAATAT 2611 ATACATTTTAAACTTTTCTAGCTGGTTTTGGGAAATTTCGAAAAATATAAATTAAAAAAAAAAAAACCGAATT

B

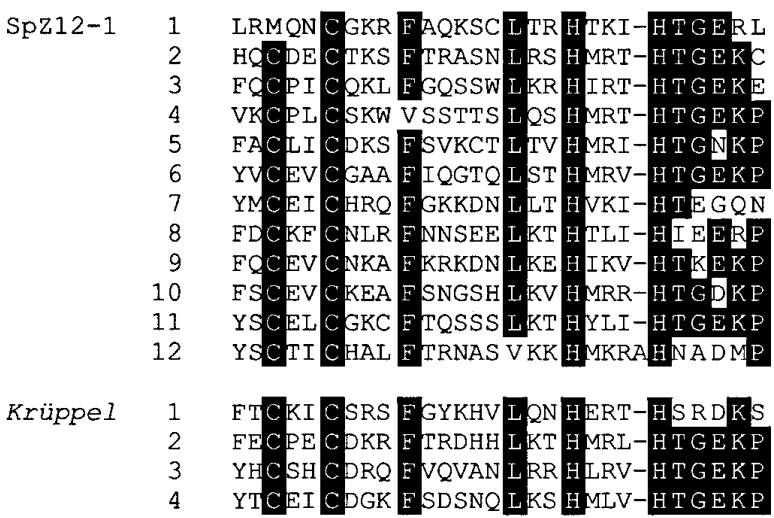


A

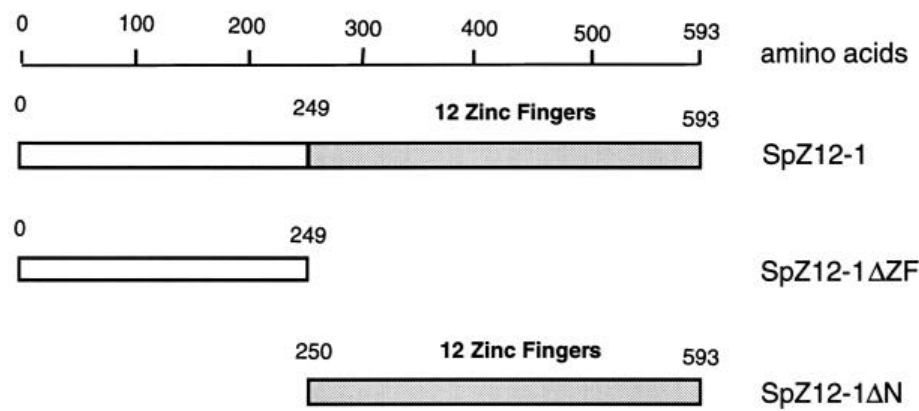

Fig. 6. Mapping the DNA-binding domain of the SpZ12-1 protein. (A) Schematic diagram of the SpZ12-1 protein and its deletion mutants. The shaded area indicates the zinc finger domain. (B) DNA-binding activity of normal and deletion mutant proteins. Gel shift assays were performed with equal amounts of SpZ12-1 and the mutant proteins as indicated. The ${ }^{32} \mathrm{P}$-labeled probe was a fragment of the CyIIIa regulatory sequence containing two adjacent SpZ12-1 binding sites extending from nucleotide -1033 to -821 . The free probe migrates to the bottom of the gel, and the upper and lower bands represent the SpZ12-1 and the SpZ12-1N complexes, respectively. The SpZ12-1 complex migrates more slowly because it is larger (approx. 590 amino acids) than the finger domain alone (approx. 350 amino acids). The small complex seen just above the free probe is probably due to degraded protein fragments. (C) Restoration of specific DNA-binding activity of EDTA-dialyzed SpZ12-1 $\Delta$ N protein by addition of $\mathrm{ZnCl}_{2}$. SpZ12-1 $\Delta \mathrm{N}$ protein samples were dialyzed against $10 \mathrm{mM}$ EDTA, $10 \mathrm{mM}$ Hepes-KOH (pH 7.9), $100 \mathrm{mM} \mathrm{KCl}, 0.5 \mathrm{M}$ guanidine hydrochloride, $1 \mathrm{mM}$ DTT, $0.1 \%$ NP-40 and $20 \%$ glycerol for 12 hours at $4{ }^{\circ} \mathrm{C}$. Gel shift assays were carried out with equal amounts $(0.5 \mu \mathrm{l})$ of control and EDTA-dialyzed SpZ12-1 $1 \Delta \mathrm{N}$ protein. Lane 1 is a control showing the SpZ12-1 $\Delta \mathrm{N}$ complex formed in the presence of $2 \mathrm{mM} \mathrm{ZnCl}_{2}$. The EDTA-dialyzed SpZ12-1 $\Delta \mathrm{N}$ protein was preincubated in the absence and presence of 2 $\mathrm{mM} \mathrm{ZnCl}_{2}$ for 5 minutes, and the ${ }^{32} \mathrm{P}$-labeled probe was then added, as shown in lane 2 and 3 , respectively.

and after renaturation (see Materials and methods) the proteins were tested for their ability to bind to the SpZ12-1 binding sites of the 5' CyIIIa regulatory region by gel shift assay. Results are shown in Fig. 6B. The SpZ12-1 and SpZ12-1 $\Delta$ N proteins bound to the ${ }^{32} \mathrm{P}$-labeled DNA probe equally well. However, no binding whatsoever was observed when the SpZ12-1 $\Delta \mathrm{ZF}$ protein was tested. These results clearly demonstrate that the DNA-binding domain of the SpZ12-1 protein is located within the $\mathrm{Zn}$ finger region. Fig. 6C shows the results of an experiment demonstrating that $\mathrm{Zn}$ ions are required for the DNAbinding activity of the SpZ12-1 protein. DNA binding is abolished by dialyzing purified SpZ12- $1 \Delta \mathrm{N}$ protein with a low concentration of EDTA, and restored when $\mathrm{ZnCl}_{2}$ is added back to the reaction mixture.

Using bacterially expressed, full-length SpZ12-1 protein, we further defined the SpZ12-1 binding sites within the 5' CyIIIa cis-regulatory region by DNase I footprinting experiments. As shown in Fig. 7A, the SpZ12-1 protein protects the two adjacent regions indicated as SpZ12-1 binding sites I and II. Alignment of the protected sequences of the sites in Fig. 7B shows that they include the inversely repeated consensus motif TGTTGC(T/C)AGG detected earlier (Thézé et al., 1990).

\section{Identification of the SpZ12-1 protein in the early embryo}

Since the SpZ12-1 clone was originally obtained by direct
B
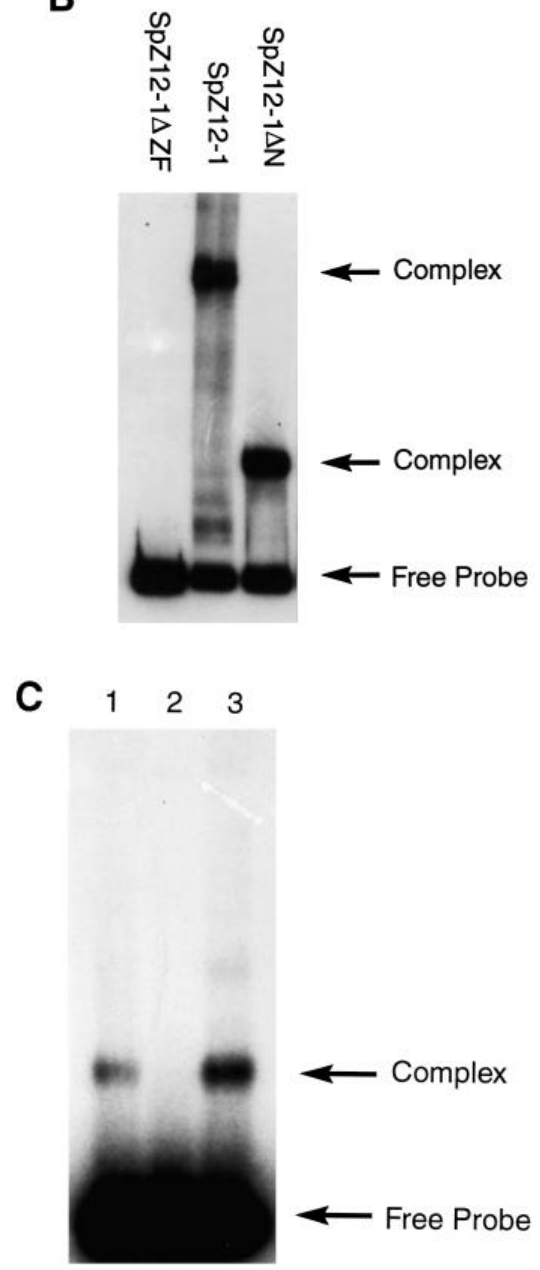

ligand screening, it was essential to determine whether the protein it encodes was present in the early embryo. A polyclonal antibody was raised against the recombinant SpZ12-1$\Delta \mathrm{ZF}$ protein, which lacks the Zn finger domain (Fig. 6). The specificity of the antibody was confirmed by reaction with both blastula-stage nuclear extracts and the full-length bacterially expressed SpZ12-1 protein (Fig. 8A). Only one immunoreactive band was detected with blastula-stage nuclear extracts, which is identical in size to the SpZ12-1 protein that is encoded by the cloned cDNA. Gel shift assays were then performed, using a blastula-stage nuclear extract and a ${ }^{32} \mathrm{P}$-labeled SpZ12-1 binding site probe. The specific SpZ12-1 proteinDNA complex was isolated from the gel; the complexed protein was released by treatment with SDS; and it was then displayed by SDS gel electrophoresis. This gel was blotted, and the filter reacted with the anti-SpZ12-1 antibody, as just described above. Fig. 8B shows that the authentic immunoreactive component of the DNA-binding complex that derived from the embryo extract is identical in size to the full-length bacterially expressed SpZ12-1 protein. Furthermore, no other proteins binding to the specific sites could be recovered from the embryo extracts. Fig. 8C shows a supershift experiment using the same polyclonal antibody. Here it can be seen that essentially all the complex is removed to either a higher molecular mass band or to an aggregate that remained bound in the well. It follows that SpZ12-1 is in all probability the 


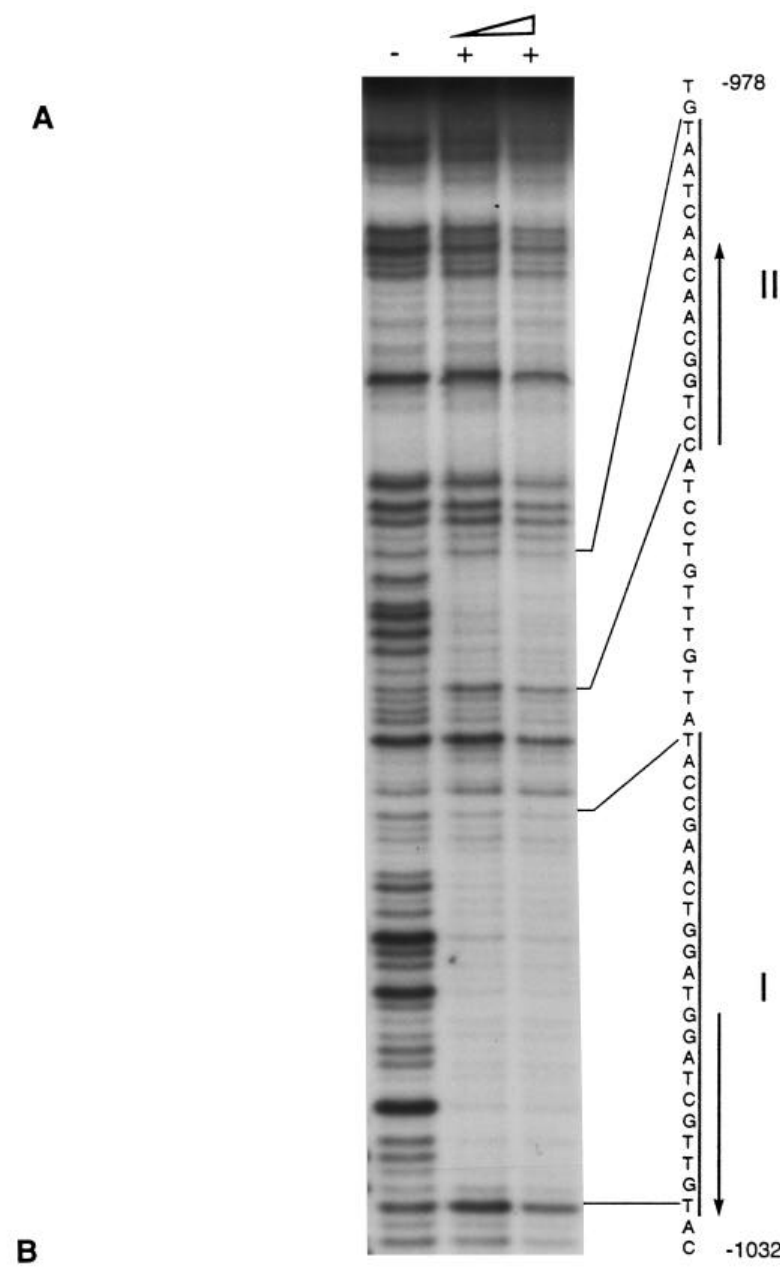

SpZ12-1 Binding Site I:

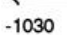
$-1008$ TGTTGCTAGGTAGGTCAAGCCAT ACAACGATCCATCCAGTTCGGTA

\section{SpZ12-1 Binding Site II: CCTGGCAACAACTAAT GGACCGTTGTTGATTA}

Fig. 7. DNase I footprinting using the bacterially expressed, fulllength SpZ12-1 protein. (A) Footprints. DNase I footprint assays were carried out with increasing amounts of bacterially expressed SpZ12-1 protein as indicated (Calzone et al., 1991). Lane (-) shows DNase I digestion pattern without added protein. The probe is the coding strand of the CyIIIa cis-regulatory region containing two SpZ12-1 binding sites $(-1033$ to -821$)$. Protected regions of sites I and II are bracketed and their sequences are underlined. The inverted repeat sequence element in each site, and their relative orientations, are indicated by the arrows. (B) Protected sequences. The nucleotides constituting the inverted repeat present in binding sites I and II are indicated in bold type.

DNA-binding factor that interacts with the target sites in the CyIII a gene that we studied, and that is responsible for the spatial repression function we identified.

\section{DISCUSSION}

\section{Identification of a negative cis-element within the $5^{\prime}$ Cyllla regulatory region}

Previous studies suggest that the CyIIIa gene is under negative spatial control in the early embryo (Franks et al., 1988, 1990; Hough-Evans et al., 1990). The first such evidence came from an interspecific experiment (Franks et al., 1988) in which ectopic spatial expression was seen when a $C y I I I a C A T$ fusion gene was injected into eggs of a distantly related second species, L. variegatus. This phenomenon implies that the normal spatial regulation of the CyIIIa gene is at least in part negative. Ectopic spatial expression can also be induced in $S$. purpuratus by an in vivo competition. If excess molar amounts of either the P3A2 or P7II sites (see Fig. 1) are coinjected with the $C y I I I a \cdot C A T$ construct, ectopic expression of CAT transcripts is also detected, in oral ectoderm, and oral ectoderm plus skeletogenic mesenchyme, respectively (Hough-Evans et al., 1990). As expected if the interactions at these sites are of negative import, the competition for the factors binding these two target sites did not significantly decrease the overall level of expression (Franks et al., 1990). In contrast, competition for the target sites of a number of other positively acting factors depresses the level of expression stoichiometrically, while the normal spatial pattern of expression remains unchanged (Franks et al., 1990; Hough-Evans et al., 1990). Recent studies have confirmed that the P3A2 and P7II binding sites are in fact required for negative spatial control of the CyIIIa gene. However, when the SpZ12-1 binding sites were coinjected in molar excess with the $C y I I I a a^{\bullet} C A T$ construct in these in vivo competition experiments, neither ectopic expression nor decrease in CAT activity was observed (Franks et al., 1990; Hough-Evans et al., 1990). This could have been due to the relatively high prevalence of SpZ12-1 protein (Calzone et al., 1988), which could have made it difficult to obtain an effective excess of competitor sites in vivo. In the present study, when the SpZ12-1 binding sites of the $C y I I I a \cdot C A T$ construct were altered by site-directed mutagenesis, approximately $46 \%$ of embryos bearing this fusion gene showed ectopic expression, specifically in mesenchyme cells, at the late gastrula stage (Table 1). This percentage directly reflects the probability of incorporation of the fusion gene into mesenchyme cell lineages during the first several cleavages (Hough-Evans et al., 1988; Sucov et al., 1988). Thus, other recent experiments carried out with a skeletogenic mesenchyme-specific construct $(S M 50 \bullet C A T)$ demonstrate that the maximal percentage of embryos with stained mesenchyme cells from a single injection is about $30-40 \%$ (unpublished data). Our results imply that all embryos that have incorporated the mutant fusion gene in skeletogenic mesenchyme cell precursors will express CAT transcripts in these cells. We conclude that the SpZ12-1 binding sites are a third negative spatial control element, interactions at which are required to repress mesenchyme cell expression of the CyIIIa gene.

\section{Late effect: repression of the Cyllla gene in skeletogenic mesenchyme cells}

The results from embryos bearing the $m Z 12 C y I I I a{ }^{\circ} C A T$ fusion gene at the mesenchyme blastula stage (Fig. 4 and Table 2), together with the data from the late gastrula stage (Fig. 4 and 
Table 1) clearly show that ectopic mesenchyme cell expression of this fusion gene occurs long after mesenchyme cell specification. It is important to note that there are several skeletogenic mesenchyme marker genes, which are activated at late cleavage stage, transcripts of which rapidly accumulate in these mesenchyme cells as ingression occurs (Benson et al., 1987; Killian et al., 1989). The skeletogenic mesenchyme is probably autonomously specified during cleavage (Davidson, 1989). Ectopic expression of CAT transcripts was not detected in skeletogenic mesenchyme cells in embryos bearing the $m Z 12 C y I I I a C A T$ fusion gene at the blastula stage, when the cells ingress into the blastocoel. Therefore, the negative function of the SpZ12-1 sites for the CyIIIa gene is not part of the initial autonomous specification program. This spatial control function appears to be required only after gastrulation. A plausible interpretation is that during the postgastrular period the CyIIIa gene begins to respond to a positive regulator that is active in both aboral ectoderm and skeletogenic mesenchyme, so the role of the repressive interaction we have studied would be to confine the effect of this positive regulator to the aboral ectoderm.

\section{SpZ12-1 is probably the particular transcription factor that exercises the negative control function we have assigned to its target site}

The argument that SpZ12-1 is in fact the sea urchin protein that binds to the CyIIIa target site we studied relies on four separate items of evidence: (i) The recombinant protein against which the antibody was raised is exactly the same size as the single immunoreactive polypeptide present in sea urchin embryo nuclear extract (Fig. 8A). (ii) A nuclear protein that reacts with this antibody is released from complexes formed with the SpZ12-1 site probe, and this protein is also identical in size to the recombinant SpZ12-1 encoded by our cDNA clone (Fig. 8B). This observation proves that SpZ12-1 is present in the sole gel shift complex formed by sea urchin embryo nuclear protein with the SpZ12-1 probe. It does not exclude the possibility that some other DNA binding protein (that the antibody does not detect) could also be present on some of the DNA probe molecules, if this other protein fortuitously produces the same size complex as does SpZ12-1. (iii) However, all of the complex present is abolished by chelation, and is restored by readdition of $\mathrm{Zn}$ (Fig. 7C), so if another DNA binding protein is present it must also be a $\mathrm{Zn}$ finger protein. (iv) Finally, we show in a supershift experiment that all of the complex is removed to higher molecular mass by the antibody against cloned SpZ12-1 (Fig. 8C). This excludes any DNA-
A binding complex other than those formed by SpZ12-1 molecules. A remaining possibility that we cannot formally exclude is that different proteins react with the SpZ12-1 site in vivo, if these proteins are for some reason excluded from our nuclear extracts. However, even crude egg lysates display only the same immunologically reactive $70 \times 10^{3} M_{\text {r }}$ proteins that produce the same characteristic SpZ12-1 gel shift complex (D. G.-W. Wang et al., unpublished data). Thus it is likely that SpZ12-1 is indeed the factor that services the CyIIIa target sites, the function of which we demonstrated in vivo. The binding activity of the SpZ12-1 protein is highly specific, as shown in the DNase I footprinting experiments (Fig. 7). Since SpZ12-1 is of maternal origin, this factor no doubt has other functions in oogenesis or early development (D. G.-W. Wang et al., unpublished data; Anderson et al., 1994).

\section{The SpZ12-1 protein}

Examination of the SpZ12-1 protein sequence reveals twelve tandem $\mathrm{Zn}$ fingers of TFIIIA type near the carboxyl terminus (Berg et al., 1990). This type of $\mathrm{Zn}$ finger is one of the most common DNA binding motifs among eukaryotic transcription factors, and can recognize a diverse set of DNA sequences (Pellegrino et al., 1991; Pavletich et al., 1993). The similarities between the finger motif of SpZ12-1 and Drosophila segmentation gene Krüppel is striking (Fig. 5B). Krüppel represents a subclass of $\mathrm{Zn}$ finger genes of the TFIIIA type that is characterized by multiple $\mathrm{Zn}$ fingers in which the canonical sequence motif $\mathrm{CX}_{2} \mathrm{CX}_{3} \mathrm{FX}_{5} \mathrm{LX}_{2} \mathrm{HX}_{3} \mathrm{H}$ is separated by highly conserved seven amino acid linkers of the form TGEKP(Y/F)X (Chowdhury et al., 1987). Recent studies of two crystal struc-

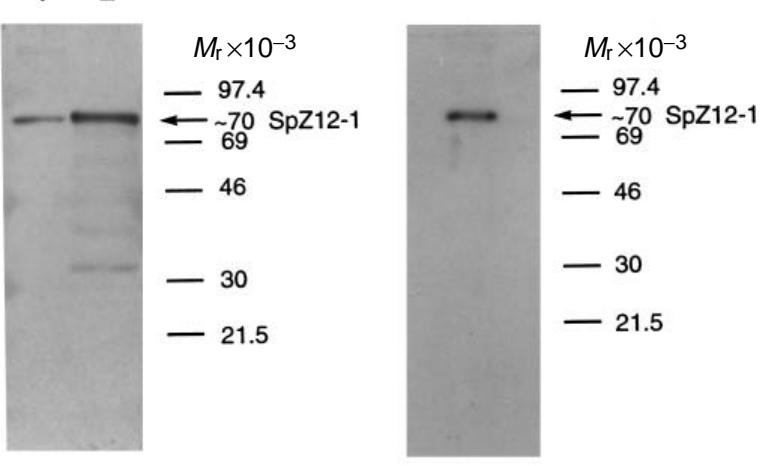

C

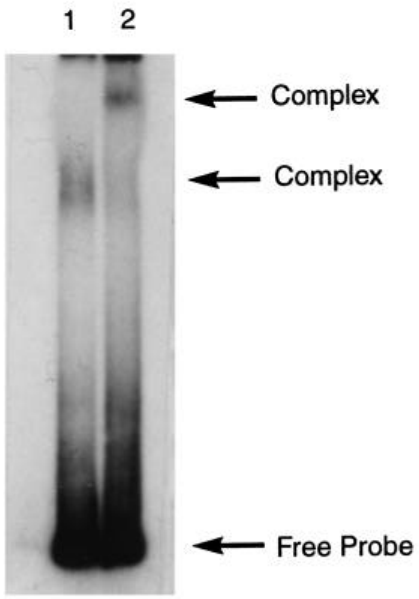

Fig. 8. Identification of the SpZ12-1 protein in blastula-stage nuclear extracts. Protein was electrophoresed on a 7\% SDS polyacrylamide gel, transferred to a nitrocellulose filter and reacted with the antibody. The positions of size markers and immunoreactive bands are indicated. (A) Lane 1 and 2 were loaded with blastula stage nuclear extract and full-length bacterially expressed SpZ12-1 protein, respectively. (B) The sample was prepared as follows: the SpZ12-1 binding site probe was mixed with late blastula-stage nuclear extracts and the complex displayed by native gel electrophoresis. A gel slice containing the SpZ12-1 protein-DNA complex was excised, minced and incubated in an SDS extraction buffer. The whole mixture was then loaded. (C) The anti-SpZ12-1 antibody supershifts the entire gel shift complex. Gel shift assays were performed using blastulastage nuclear extracts as previously described (Calzone et al., 1988). After the binding reaction, 5 $\mu \mathrm{l}$ of the antibody was added to the reaction mixture for 10 minutes at $4{ }^{\circ} \mathrm{C}$. 
tures of the $\mathrm{Zn}$ finger proteins, Egr 1 and GLI-1 with their cognate DNA-binding sites, show that each $\mathrm{Zn}$ finger domain can independently bind DNA and that each recognizes a threenucleotide sequence; in the case of GLI-1, not all of the five Zn fingers contact the DNA; i.e., not all Zn fingers contribute equally to DNA recognition (Pavletich et al., 1991, 1993). Consistent with this observation, our data demonstrate that the twelve-Zn finger region of SpZ12-1 recognizes only a 23nucleotide target site (Fig. 7B), implying that probably four to five of the $\mathrm{Zn}$ fingers are not involved in the interaction displayed by the footprint at each site. The SpZ12-1 protein sequence does not have significant similarities to any other proteins outside the $\mathrm{Zn}$ finger domain. For instance, despite the fact that the fingers of SpZ12-1 and Krüppel are similar, the amino-terminal region of SpZ12-1 has no similarity with the highly conserved Krüppel-associated box (KRAB). This is a 75-amino acid domain present in the amino-terminal region of more than one-third of all Krüppel subclass Zn finger proteins, which is probably responsible for transcriptional repression mediated by these factors (Margolin et al., 1994; Witzgall et al., 1994).

SpZ12-1 contains many potential sites for phosphorylation, but the significance of this is hard to evaluate due to the preponderance of serine, threonine and proline residues in the sequence. Our recent studies have revealed that a number of SpZ12-1 variants are present in the early embryo which can be resolved by two-dimensional gel electrophoresis. These variants appear to be the consequence of posttranslational modifications (D. G.-W. Wang and M. G. Harrington, unpublished observations). Since SpZ12-1 is maternal and is present in both cytoplasm and nucleus of the early embryo (D. G.-W. Wang et al., unpublished data) such posttranslational modifications could be the means of controlling the nuclear localization of SpZ12-1, or its regulatory function in the nucleus.

In conclusion, we have identified a specific negative spatial cis-regulatory function that controls CyIIIa expression in the skeletogenic mesenchyme of late embryos. The trans-factor which exercises this function is probably SpZ12-1. Since we know the cell type and stage in which this function of SpZ121 is required, we are now in a position to determine the modifications that determine its temporal and spatial activity.

We thank Dr Christer Höög, Ann E. Cutting and Vikas Duvvuri for technical assistance, Dr Kirsten L. Rood for critically editing a draft of the manuscript, and Professors Ellen Rothenberg and Scott E. Fraser for valuable remarks. This research was supported by NIH Grant HD05753. D. G. W. was supported by a McCallum Fellowship, California Biochemical Foundation and NIH Grant HD-05753. C. V. K. was supported by a training grant from the Austrian government.

\section{REFERENCES}

Akhurst, R. J., Calzone, F. J., Lee, J. J. Britten, R, J. and Davidson, E. H. (1987). Structure and organization of the CyIII actin gene subfamily of the sea urchin Strongylocentrotus purpuratus. J. Mol. Biol. 194, 193-203.

Anderson, R., Britten, R. J. and Davidson, E. H. (1994). Repeated sequence target sites for maternal DNA-binding proteins in genes activated in early sea urchin development. Dev. Biol. 163, 11-18.

Barberis, A., Superti-Furga, G. and Busslinger, M. (1987). Mutually exclusive interaction of the CCAAT-binding factor and a displacement protein with overlapping sequences of a histone gene promoter. Cell 50, 347359.

Benson, S., Sucov, H. M., Stephens, L., Davidson, E. H. and Wilt, F. H.
(1987). A lineage-specific gene encoding a major matrix protein of the sea urchin embryo spicule. I. Authentication of the cloned gene and its developmental expression. Dev. Biol. 120, 499-506.

Berg, J. M. (1990). Zinc finger domains: hypotheses and current knowledge. Ann. Rev. Biophys. Biophys. Chem. 19, 405-421.

Calzone, F. J., Thézé, N., Thiebaud, P., Hill, R. L., Britten, R. J. and Davidson, E. H. (1988). Developmental appearance of factors that bind specifically to $c$ s-regulatory sequences of a gene expressed in the sea urchin embryo. Genes Dev. 2, 1074-1088.

Calzone, F. J., Höög, C., Teplow, D. B., Cutting, A. E., Zeller, R. W., Britten, R. J. and Davidson, E. H. (1991). Gene regulatory factors of the sea urchin embryo I. Purification by affinity chromatography and cloning of P3A2, a novel DNA-binding protein. Development 112, 335-350.

Cameron, R. A. and Davidson, E. H. (1991). Cell-type specification during sea urchin development. Trends Genet. 7, 212-218.

Char, B. R., Bell, J. R., Dovala, J.,Coffman, J. A., Harrington, M. J., Becerra, J.C., Davidson, E. H., Calzone, F. J. and Maxson, R. (1993). SpOct, a gene encoding the major octamer-binding protein in sea urchin embryos: expression profile, evolutionary relationships, and DNA binding of expressed protein. Dev. Biol. 158, 350-363.

Chowdhury, K., Deutsch, U. and Gruss, P. (1987). A multigene family encoding several 'finger' structures is present and differentially active in mammalian genomes. Cell 48, 771-778.

Coffman, J. A. and Davidson, E. H. (1992). Expression of spatially regulated genes in the sea urchin embryo. Curr. Opin. Genet. Dev. 2, 260-268.

Cox, K. H., Angerer, L. M., Lee, J. J., Britten, R. J., Davidson, E. H. and Angerer, R. C. (1986). Cell lineage-specific programs of expression of multiple actin genes during sea urchin embryogenesis. J. Mol. Biol. 188, 159172

Davidson, E. H. (1986). Gene Activity in Early Development 3rd ed., Orlando, FL: Academic Press.

Davidson, E. H. (1989). Lineage-specific gene expression and the regulative capacities of the sea urchin embryo: a proposed mechanism. Development 105, 421-445.

Flytzanis, C. N., Britten, R. J. and Davidson, E. H. (1987). Ontogenic activatin of a fusion gene introduced into the sea urchin egg. Proc. Natl. Acad. Sci. USA 84, 151-155.

Franks, R. R., Anderson, R., Moore, J. G., Hough-Evans, B. R., Britten, R. J. and Davidson, E. H. (1990). Competitive titration in living sea urchin embryos of regulatory factors required for expression of the CyIIIa actin gene. Development 110, 31-40.

Franks, R. R., Hough-Evans, B. R., Britten, R. J. and Davidson, E. H. (1988). Spatially deranged though temporally correct expression of a Strongylocentrotus purpuratus actin gene fusion in transgenic embryos of a different sea urchin family. Genes Dev. 2, 1-12.

Hickey, R. J., Boshar, M. F. and Crain, W. R. (1987). Transcription of three actin genes and a repeated sequence in isolated nuclei of sea urchin embryos. Dev. Biol. 124, 215-225.

Höög, C., Calzone, F. J., Cutting, A. E., Britten, R. J. and Davidson., E. H. (1991). Gene regulatory factors of the sea urchin embryo II. Two dissimilar proteins, P3A1 and P3A2, bind to the same target sites that are required for early territorial gene expression. Development 112, 351-364.

Hough-Evans, B. R., Franks, R. R., Cameron, R. A., Britten, R. J. and Davidson, E. H. (1987). Correct cell type-specific expression of a fusion gene injected into sea urchin eggs. Dev. Biol. 121, 576-579.

Hough-Evans, B. R., Britten, R. J. and Davidson, E. H. (1988). Mosaic incorporation and regulated expression of an exogenous gene in the sea urchin embryo. Dev. Biol. 129, 198-208.

Hough-Evans, B. R., Franks, R. R., Zeller, R. W., Britten, R. J. and Davidson, E. H. (1990). Negative spatial regulation of the lineage-specific CyIIIa actin gene in the sea urchin embryo. Development 110, 41-50.

Killian, C. E. and Wilt, F. H. (1989). The accumulation and translation of a spicule matrix protein mRNA during sea urchin embryo development. Dev. Biol. 133, 148-156.

Lee, J. J., Calzone, F. J., Britten, R. J., Angerer, R. C. and Davidson, E. H. (1986). Activation of sea urchin actin genes during embryogenesis measurement of transcript accumulation from five different genes in Strongylocentrotus purpuratus. J. Mol. Biol. 188, 173-183.

Livant, D., Cutting, A., Britten, R. J. and Davidson, E. H. (1988). Titration of the activity of a fusion gene in intact sea urchin embryos. Proc. Natl. Acad. Sci. USA 85, 7607-7611.

Livant, D., Hough-Evans, B. R., Moore, J. G., Britten, R. J. and Davidson, E. H. (1991). Differential stability of expression of similarly specified 
endogenous and exogenous genes in the sea urchin embryo. Development 113, 385-398.

Margolin, J. F., Friedman, J. R., Meyer, W. K.-H., Vissing, H., Thiesen, H.J. and Rauscher, F. J., III. (1994). Krüppel-associated boxes are potent transcriptional repression domains. Proc. Natl. Acad. Sci. USA 91, 45094513.

McMahon, A. P., Flytzanis, C. N., Hough-Evans, B. R., Katula, K. S., Britten, R. J. and Davidson, E. H. (1985). Introduction of cloned DNA into sea urchin egg cytoplasm: replication and persistence during embryogenesis. Dev. Biol. 108, 420-430.

Pavletich, N. P. and Pabo, C. O. (1991). Zinc finger-DNA recognition: crystal structure of a Zif268-DNA complex at 2.1 A. Science 252, 809-817.

Pavletich, N. P. and Pabo, C. O. (1993). Crystal structure of a five-finger GLIDNA complex: new perspective on zinc fingers. Science 261, 1701-1707.

Pellegrino, G. R. and Berg, J. M. (1991). Identification and characterization of 'zinc finger' domains by the polymerase chain reaction. Proc. Natl. Acad. Sci. USA 88, 671-675.

Ransick, R., Ernst, S. J., Britten, R. J. and Davidson, E. H. (1993). Whole mount in situ hybridization shows Endo 16 to be a marker for the vegetal plate territory in sea urchin embryos. Mech. Dev. 42, 117-124.

Rosenberg, U. B., Schröder, C., Preiss, A., Kienlin, A., Côté, S., Riede, L. and Jäckle, H. (1986). Structural homology of the product of the Drosophila Krüppel gene with Xenopus transcription factor IIIA. Nature 319, 336-339.

Shott, R. J., Lee, J. J., Britten, R. J. and Davidson, E. H. (1984). Differential expression of the actin gene family of Strongylocentrotus purpuratus. Dev. Biol. 101, 295-306.
Studier, F. W. and Moffat, B. A. (1986). Use of bacteriophage T7 RNA polymerase to direct selective high-level expression of cloned genes. J. Mol. Biol. 189, 113-130.

Sucov, H. M., Hough-Evans, B. R., Franks, R. R., Britten, R. J. and Davidson E. H. (1988). A regulatory domain that directs lineage-specific expression of a skeletal matrix protein gene in the sea urchin embryo. Genes Dev. 2, 1238-1250.

Thézé, N., Calzone, F. J., Thiebaud, P., Hill, R. L., Britten, R. J. and Davidson, E. H. (1990). Sequence of the CyIIIa actin gene regulatory domain bound specifically by sea urchin embryo nuclear proteins. Mol. Reprod. Dev. 25, 110-122.

Vinson, C. R., LaMarco, K. L., Johnson, P. F., Landschultz, W. H. and McKnight, S. L. (1988). In situ detection of sequence-specific DNA binding activity specified by a recombinant bacteriophage. Genes Dev. 2 , 801-806.

Witzgall, R., O'Leary, E., Laef, A., Önaldi, D. and Bonventre, J. V. (1994). The Krüpple-associated box-A (KRAB-A) domain of zinc finger proteins mediates transcriptional repression. Proc. Natl. Acad. Sci. USA 91, 45144518.

Yuh, C.-H., Ransick, A., Martinez, P., Britten, R. J. and Davidson, E. H. (1994). Complexity and organization of DNA-protein interactions in the $5 \varnothing$ regulatory region of an endoderm-specific marker gene in the sea urchin embryo. Mech. Dev. 47, 165-186.

(Accepted 3 January 1995) 